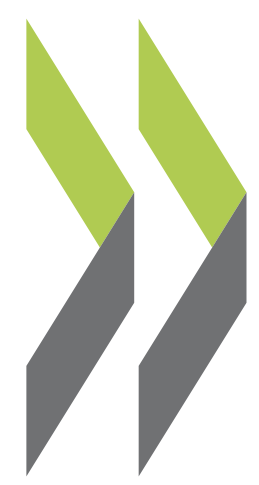

OECD Economics Department Working Papers No. 605

\title{
Managing Chile's \\ Macroeconomy during and after the Copper Price Boom
} Luiz de Mello 
Organisation de Coopération et de Développement Économiques

Organisation for Economic Co-operation and Development

14-Apr-2008

ECONOMICS DEPARTMENT

English - Or. English

MANAGING CHILE'S MACROECONOMY DURING AND AFTER THE COPPER PRICE BOOM

ECONOMICS DEPARTMENT WORKING PAPERS No. 605

By

Luiz de Mello

All Economics Department Working Papers are available through OECD's Internet Web site at: http://www.oecd.org/eco/Working_Papers

JT03244076 


\section{ABSTRACT/RESUME \\ Managing Chile's macroeconomy during and after the copper price boom}

Compliance with the structural budget surplus rule, which has been in place since 2001, has allowed the government to maintain a counter-cyclical fiscal stance in an environment of rising copper prices, while delivering a gradual reduction in public indebtedness. Monetary policy is conducted within a framework that combines inflation targeting with exchange-rate flexibility. A Fiscal Responsibility Law was promulgated in September 2006, strengthening the macroeconomic framework further by embedding the fiscal rule in law and setting out regulations for the use of fiscal savings. Complementary pension reform is being discussed in Congress with the objective of strengthening the pension system's solidarity pillar and encouraging retirement saving. The tax system is also being improved with a view to removing obstacles to financial deepening and to business-sector development. Government spending on social programmes is budgeted to rise considerably, in line with the authorities' emphasis on social development. The main challenge in the macroeconomic area is to maintain the policy setting that has served Chile so well over the recent copper-price upswing, while tempering demands for hiking public social spending and maintaining a lean public sector in a low-tax, low-debt environment. This paper relates to the 2007 Economic Survey of Chile (www.oecd.org/eco/surveys/chile).

JEL codes: E20, E52, E62

Keywords: Chile, monetary policy, fiscal policy, pension reform

$* * * * * * * *$

\section{La gestion macroéconomique du Chili durant et après la forte hausse des prix du cuivre}

Respectant la règle d'excédent budgétaire structurel, appliquée depuis 2001, le gouvernement a pu maintenir une orientation budgétaire anticyclique dans un contexte de hausse des prix du cuivre tout en réduisant progressivement la dette publique. La politique monétaire s'appuie sur un cadre associant le ciblage de l'inflation à un taux de change flexible. Une loi de responsabilité budgétaire, adoptée en septembre 2006, a encore renforcé le dispositif macroéconomique en conférant un caractère législatif à la règle budgétaire et en réglementant l'utilisation des économies budgétaires. Une réforme complémentaire des retraites est actuellement examinée par le Congrès, son but étant de consolider le régime fondé sur la solidarité et d'encourager l'épargne retraite. Les autorités s'efforcent également d'améliorer le système fiscal afin d'éliminer les obstacles au développement du secteur financier et du secteur des entreprises. Les dépenses publiques devraient beaucoup augmenter pour les programmes sociaux, l'accent étant mis sur le développement social. Le principal enjeu macroéconomique est de préserver le cadre d'action qui a été si bénéfique pour le Chili durant la forte hausse récente des prix du cuivre, tout en tempérant les revendications d'augmentation des dépenses publiques sociales et en conservant un secteur public dimensionné au plus juste dans un environnement de faible fiscalité et de faible endettement. Ce document se rapporte à l'Étude économique du Chili 2007 (www.oecd.org/eco/etudes/chili).

Classification JEL : E20, E52, E62

Mots-clés : Chili, politique monétaire, politique budgétaire, réforme des pensions

Copyright $\odot$ OECD, 2008. All rights reserved. Application for permission to reproduce or translate all, or part of, this material should be made to: Head of Publications Service, OECD, 2 rue André-Pascal, 75775 PARIS CEDEX 16, France. 


\section{Table of contents}

Managing Chile's macroeconomy during and after the copper price boom.......................................5

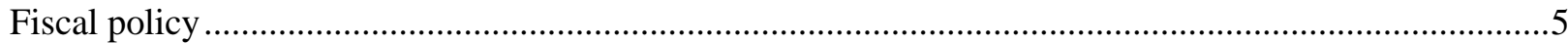

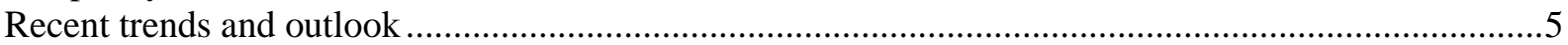

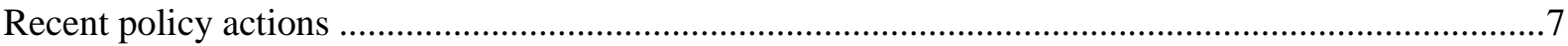

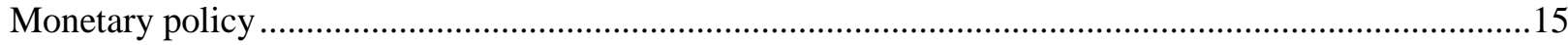

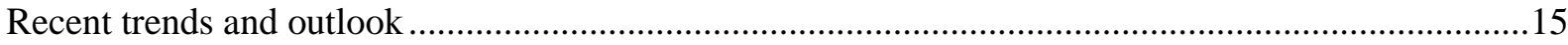

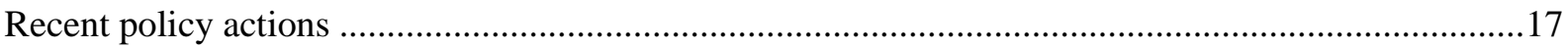

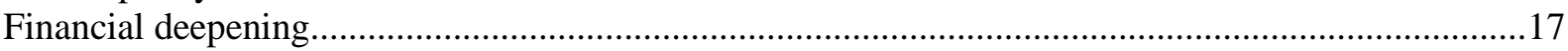

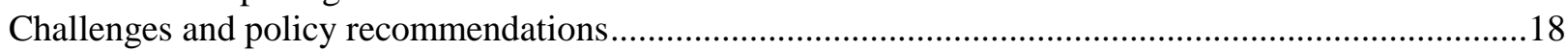

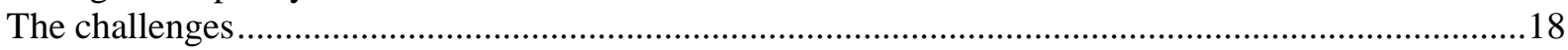

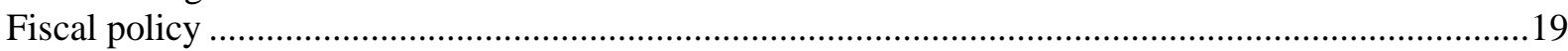

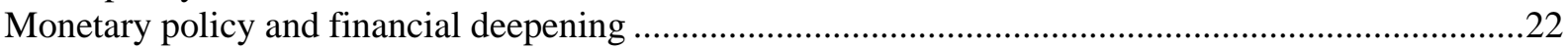

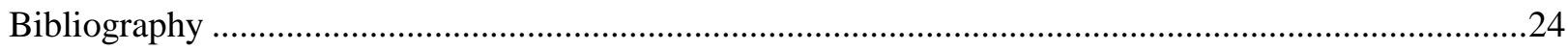

Annex Al Fiscal policy over the business and copper-price cycles .....................................................26

Annex A2 Monetary policy and inflation expectations: Long-run effects.............................................28

\section{Boxes}

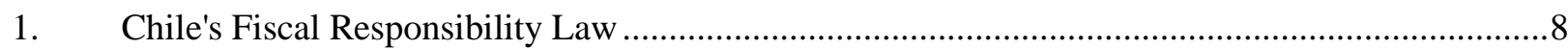

2. The pension system: An overview of the current system and background to the reform

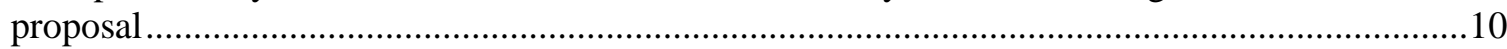

3. Chile's tax system: An overview and main issues ……........................................................13

\section{Tables}

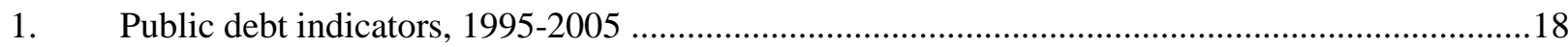

A1.1. Fiscal policy over the business and copper price cycles, 199-2006 ........................................27

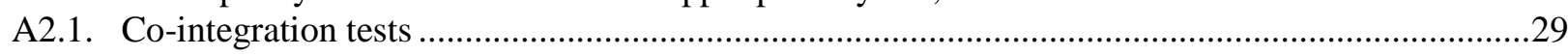

\section{Figures}

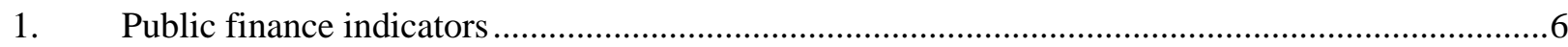

2. Fiscal policy over the business and copper price cycles, 1987-2006 .........................................

3 Composition of central government spending, 1990-2005 .......................................................

4. Composition of central government tax revenue, 1995-2005 ….............................................14

5. Monetary stance, exchange rate and unit labour costs: Recent trends ........................................16 
ECO/WKP(2008)13 
ECO/WKP(2008)13

\title{
Managing Chile's macroeconomy during and after the copper price boom
}

\author{
By \\ L. de Mello ${ }^{1}$
}

Chile's macroeconomic performance remains strong. Compliance with the structural budget surplus rule, which has been in place since 2001, has allowed the government to achieve a net creditor position. Monetary policy continues to be conducted within a policy framework combining inflation targeting and a floating exchange-rate regime. This has anchored expectations within the target range of 2 to $4 \%$. To consolidate the gains achieved so far and to address remaining policy challenges, the institutional framework for macroeconomic policy-making continues to be strengthened. The tax system is also being improved with a view to removing obstacles to financial deepening and to business-sector development. The main challenge in the macroeconomic area is to maintain the policy setting that has served Chile so well over the current copper-price upswing. The sustainability of planned increases in social spending over the longer term will need to be assessed carefully against the need to prepare for: $i$ ) contingencies associated with the pension system; $i$ i) the additional counter-cyclical elements recently embedded in the structural budget surplus rule; and iii) the foregone revenue associated with measures that could improve the efficiency of the tax system.

\section{Fiscal policy}

\section{Recent trends and outlook}

The robust copper price boom of the last three years has put the fiscal framework to the test. Due to continued adherence to the structural budget surplus rule, which was maintained by the current administration upon taking office in March 2006, the consolidated (central government and central bank) budget surplus rose to nearly 8\% of GDP in 2006 (Ministry of Finance, 2006a) (Figure 1). Consistently, the gross consolidated public debt-to-GDP ratio came down to less than 25\% of GDP at end-2006 as a result of several years of robust fiscal performance. Owing to this reduction in gross indebtedness, coupled with a further accumulation of assets during 2006, the consolidated net debt is now negative. The level of indebtedness of the public-enterprise sector is also declining gradually to around 5.5\% of GDP on a net basis at end-2006, as is the stock of publicly guaranteed debt (about 1.5\% of GDP at end-2006) and recognition bonds (about 12\% of GDP at end-2006) associated with the pension reform of the early 1980s (discussed in the 2005 Survey; OECD, 2005).

1. This paper is part of the Economic Survey of Chile published in November 2007 under the authority of the Secretary General of the OECD and discussed at the Economic and Development Review Committee on 9 October 2007. The author thanks, without implicating, the Chilean authorities for helpful comments and discussions. Special thanks are due to Anne Legendre for research assistance and Mee-Lan Frank for excellent technical assistance. 


\section{A. Budget outturn, 1991-2007}

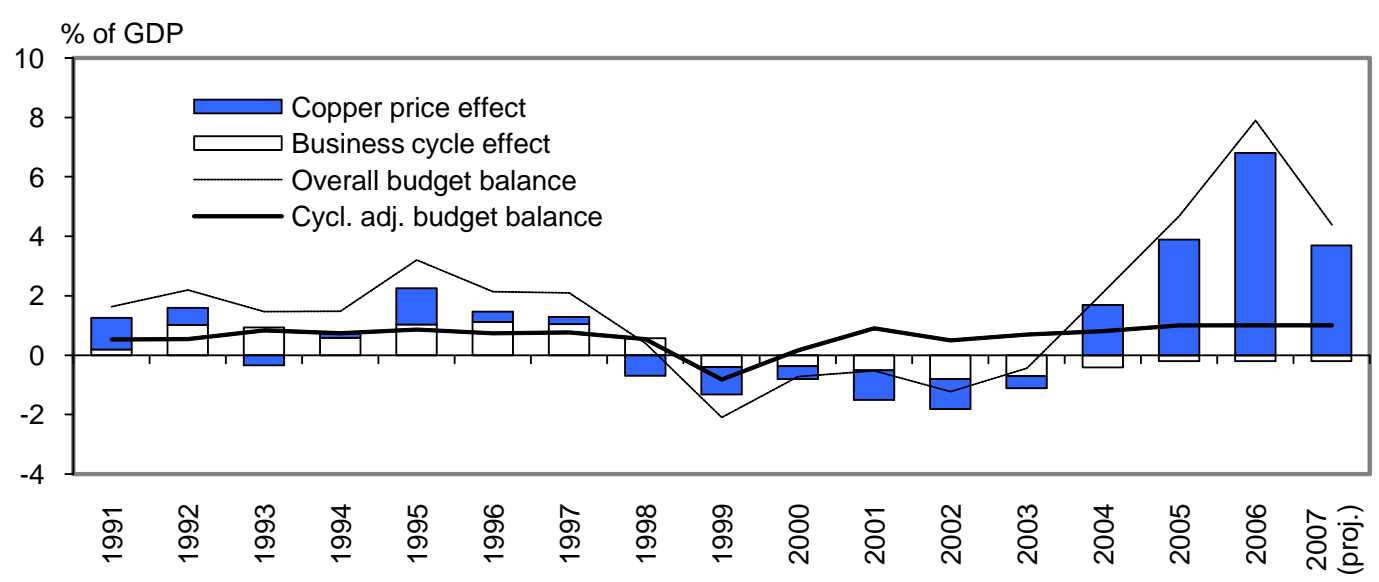

\section{B. Copper price and stabilisation fund, 1990-2006}

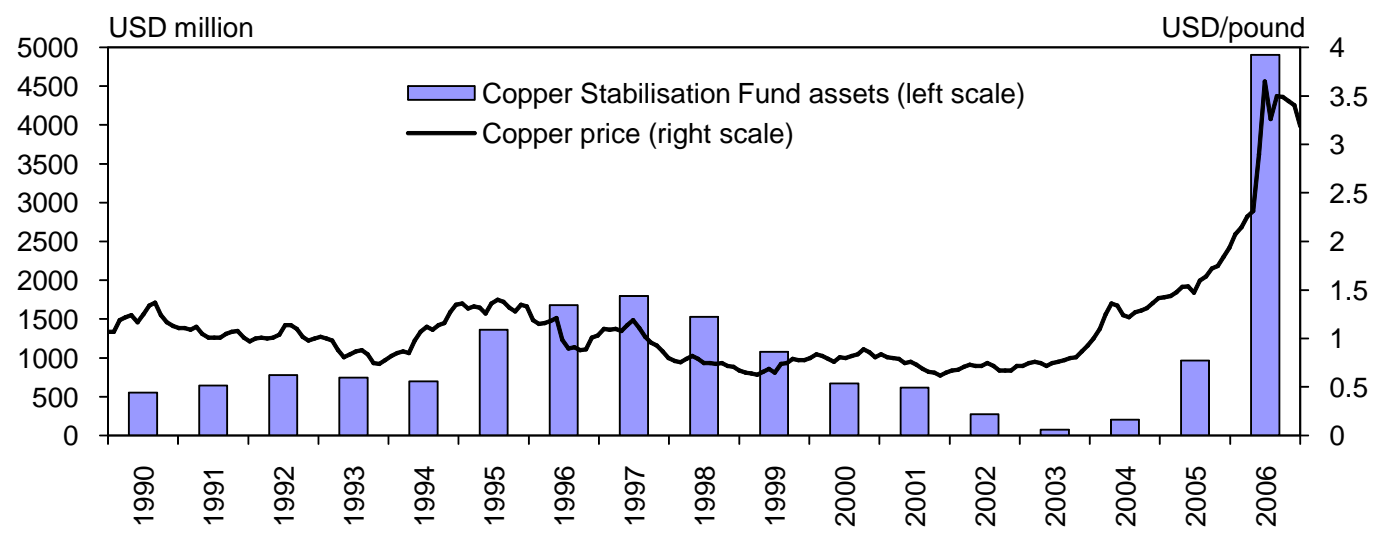

Source: Ministry of Finance and OECD calculations.

Low indebtedness and the introduction of the structural budget balance rule in 2001 have reduced the scope for fiscal activism. The correlation between the deviation of the price of copper from its long-term trend and the fiscal stance, measured by the cyclically-adjusted primary budget balance, appears to be weakening over time (Figure 2). This is confirmed by the empirical analysis reported in Annex A1.1, which suggests that Chile's fiscal reaction function is well defined: the fiscal stance responds strongly to the level of net public indebtedness, and fiscal activism contributed to debt reduction, at least until 2001, when the positive impact on public finances of cyclical improvements in the business and copper price cycles had been complemented by discretionary action. This behaviour has allowed for a gradual reduction in the net debt-to-GDP ratio over the years. Since 2001, however, there appears to have been less fiscal activism, a development that is likely attributable to continued compliance with the fiscal rule in an environment of low indebtedness. However, it may be too early to ascertain the extent to which a reduction in business-cycle fluctuations in recent years can be ascribed essentially to the reformed policy framework, 
Figure 2. Fiscal policy over the business and copper price cycles, 1987-2006

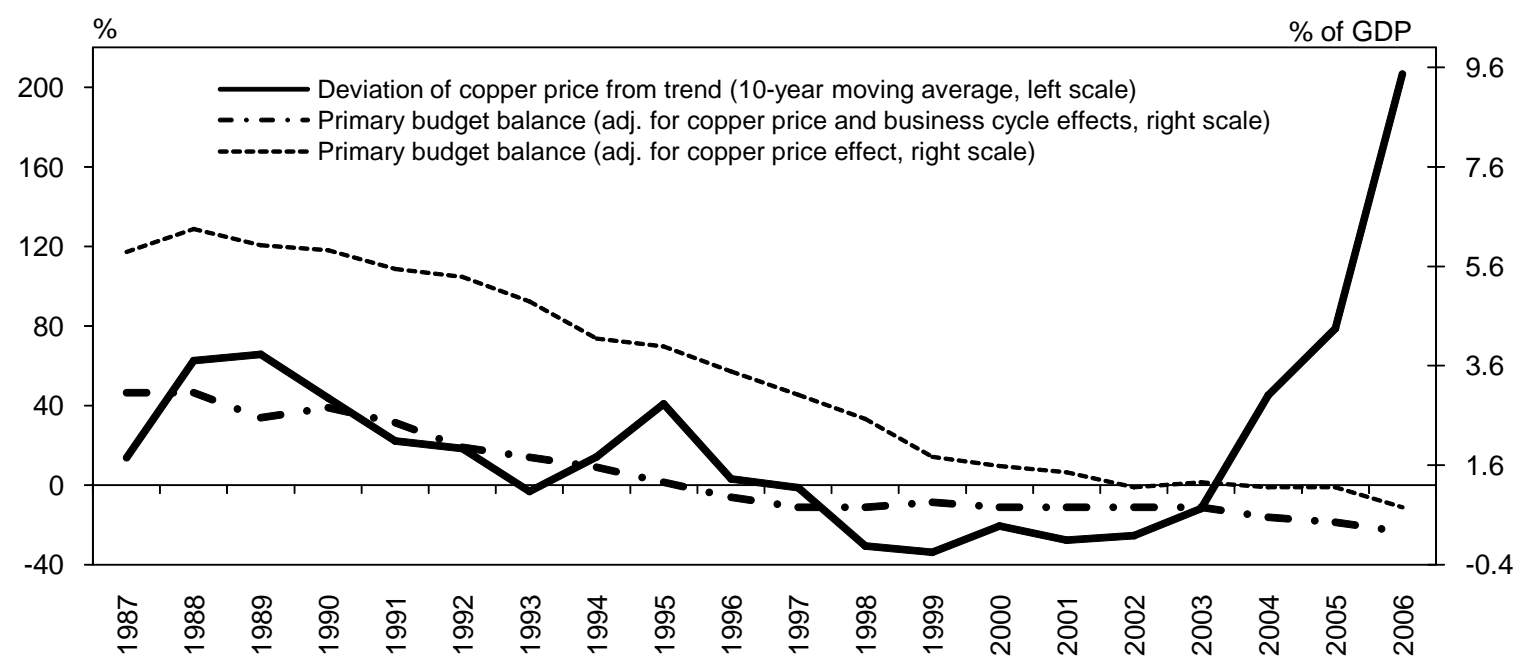

Source: IMF (International Financial Statistics), Central Bank of Chile, Ministry of Finance and OECD calculations.

which has undoubtedly been a major contributor, or to changes in the nature of shocks hitting the economy. ${ }^{2}$

The composition of government spending has improved simultaneously with fiscal consolidation. A reduction in outlays on interest payments, on the back of a sustained reduction in public indebtedness, has allowed the government to raise budgetary allocations for social programmes (social protection, education and health care) (Figure 3). This trend reflects the authorities' heightened policy emphasis on social development over the years. Nevertheless, as discussed in Moccero (2008), the shares in GDP of government spending on education and health care are still well below the OECD average, which reflects to some extent a reliance on private financing, especially in the areas of tertiary education and health care.

\section{Recent policy actions}

\section{The Fiscal Responsibility Law}

The enactment of the Fiscal Responsibility Law (FRL) in September 2006 was an important step in strengthening the fiscal framework. The FRL embeds the structural budget surplus rule in law and introduces explicit formal mechanisms for capitalising the central bank and for dealing with pension-related contingencies, as recommended in the OECD (2005) (Box 1). At the same time, the methodology for calculating the structural budget surplus target was adjusted to include revenue from molybdenum - a copper derivative that Chile exports in large amounts and whose price has been volatile in international markets, thereby affecting public finances - and those accruing from the taxation of privately-owned mining companies.

2. De Mello and Moccero (2007) estimate a structural model for four Latin American inflation targeters (Brazil, Chile, Colombia and Mexico) and conduct counterfactual exercises to test whether volatility in interest rates, inflation and the output gap changed significantly after adoption of inflation targeting coupled with exchange rate flexibility in these countries. The results for Chile suggest that the interest rate became less volatile after September 1999, when the peso was allowed to float, due to milder shocks in an environment where monetary policy has been unencumbered by the need to defend an exchange-rate peg. 
Figure 3. Composition of central government spending, 1990-2005

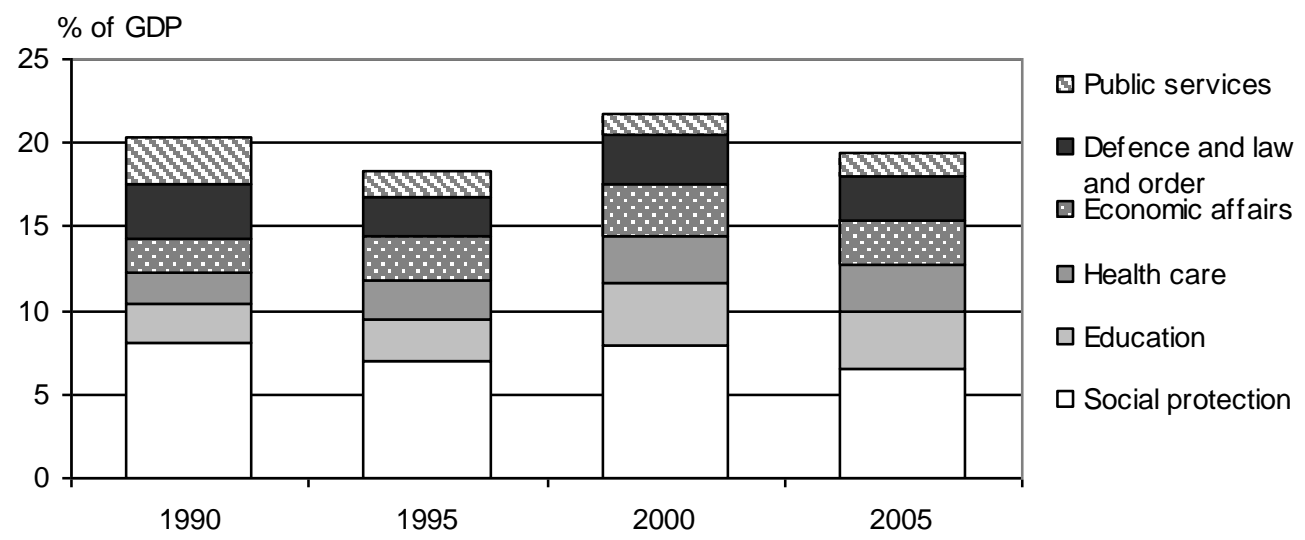

Source: Ministry of Finance.

\section{Box 1. Chile's Fiscal Responsibility Law}

Enacted in September 2006, the Fiscal Responsibility Law (FRL):

- $\quad$ Creates the Fund for Economic and Social Stabilisation (Fondo de Estabilisación Económica y Social), the Pensions Reserve Fund (Fondo de Reserva de Pensiones) and the Contingency Unemployment Programme (Programa de Contingencia contra el Desempleo). Initial allocations for the Stabilisation and Pensions Reserve funds were set at a total of about USD 6.6 billion, financed by accumulated budgetary savings.

- Sets rules for a gradual recapitalisation of the central bank through phased capital transfers from the Treasury.

- $\quad$ Strengthens the institutional status of the structural budget surplus rule by requiring the government to state in its budget documentation the impact of policy changes on the structural budget balance.

\section{The initiatives: A brief description}

The Unemployment Programme

The Unemployment Programme enhances fiscal counter-cyclicality by allowing government spending on job-creation programmes if the unemployment rate exceeds either $10 \%$ in a given quarter or the quarterly average of the rate in the previous five years. Policy action is also allowed in communes where the unemployment rate is above $10 \%$, regardless of the level of unemployment in the province where they are located. Information on the programmes financed by the government will be reported by the Ministries of Finance and Labour.

\section{The Pensions Reserve Fund}

The Pensions Reserve Fund provides contingent funding for the payment of assistance pensions and minimum pension guarantees. The Fund will be capitalised through annual transfers from the Treasury of at least $0.2 \%$ of previous year's GDP (capped at $0.5 \%$ of previous year's GDP). Capital injections will persist until the Fund has accumulated assets (including the return on investments) equivalent to 900 million UFs (about USD 30 billion in April 2007). Fund assets can be used to finance the payment of pension contingencies only 10 years after enactment of the FRL. The outlays financed by the Fund each year cannot exceed one-third of the total of planned spending on assistance pensions and minimum pension guarantees in the reference year and the projected spending on these programmes in 2015. Fund assets will be managed by the Treasury and can be invested in Chile and abroad. 
As discussed in the OECD (2005), individuals who have contributed for at least 20 years to a personal fund but have not been able to save enough to ensure a retirement income at least as high as the minimum pension are entitled to a means-tested minimum pension paid by the government. The fiscal cost associated with this entitlement is a main source of contingent liabilities for the central government, because this cost is affected by uncertainty about the financial performance of pension funds, developments in labour markets and the trajectory of individual contribution density (i.e. actual number of months of contribution over total potential months of contribution) over time.

The other pension-related contingency is associated with the payment of means-tested, general revenue-financed assistance pensions to those individuals whose contribution history falls short of the minimum required duration and who do not have alternative sources of income. The assistance pension is not an entitlement, unlike the minimum pension guarantee, because the aggregate budgetary allocation for these pensions is set by the government in the budget-making process, and, therefore, the value of these benefits depends on the number of beneficiaries. But the value of these benefits, which is currently about one-half of that of the minimum pension, may rise over the years, particularly as society becomes wealthier and presumably puts a higher premium on equity considerations.

\section{The Fund for Economic and Social Stabilisation}

All remaining budget surplus is allocated to this Fund. Operations are disclosed regularly, and prudential regulations allow for investment in high-grade corporate and government securities abroad.

\section{Recapitalisation of the central bank}

The FRL allows the Treasury to recapitalise the BCCh on a yearly basis for a period of five years by an amount that is equivalent to the budget surplus minus the capital injection into the Pensions Reserve Fund up to a ceiling of $0.5 \%$ of the previous year's GDP. The BCCh's net worth is estimated at $-1.4 \%$ of GDP in 2008 , considering a capital injection of $0.5 \%$ of GDP in July 2007 , but excluding future losses associated with non-performing loans in the central bank's portfolio.

Chile is in the fortunate position of implementing the FRL at a time when fiscal consolidation has been secured. Typically, fiscal responsibility legislation has been introduced in the OECD area and in other Latin American countries, such as Argentina, Brazil and Peru, prior to, and in support of, fiscal consolidation and as an integral part of institutional reform in the fiscal area. Such fiscal rules therefore focus on the introduction of numerical ceilings/targets for the budget balance and/or level of indebtedness. In the Chilean context, however, the FRL institutionalises an existing fiscal rule - the structural budget surplus rule, which is well entrenched but hitherto not embedded in law - while explicitly introducing formal mechanisms for investing the savings accruing from continued adherence to the fiscal rule in an environment of low indebtedness and very supportive copper prices.

\section{Further pension reform}

Policy action has also aimed at addressing the remaining weaknesses of the pension system. As discussed in OECD (2005), the Chilean pension system suffers from low coverage of social security and low density of contributions (Box 2). It was argued then that the time was ripe for addressing these challenges because of the comfortable fiscal position and the projected reduction in government spending on other pension-related commitments, including the redemption of recognition bonds issued to cover the transition costs of the early 1980s reform. Consistent with this policy advice, a Commission was set up in 2006 (Consejo Asesor Presidencial para la Reforma Previsional) to assist the authorities by proposing reform options. Legislation was subsequently submitted to Congress in December 2006 laying out the main elements of reform. 
ECO/WKP(2008)13

\section{Box 2. The pension system: An overview of the current system and background to the reform proposal}

\section{An overview of the system ${ }^{1}$}

The Chilean pay-as-you-go (PAYG) pension system was reformed in the early 1980s with the creation of a "three-pillar" system:

- The first pillar corresponds to: $i$ ) the minimum income guarantee (PMG) provided by the government for those individuals aged 65 years (60 years for women) who have contributed to a pension fund for at least 20 years but whose accumulated savings are insufficient to finance a minimum pension upon retirement; ii) the means-tested, general revenue-financed assistance pension (PASIS) paid to those workers (aged 65 years and above) who do not have another source of income; and iii) the military and national police schemes. While the minimum pension guarantee is an entitlement, payment of an assistance pension is not.

- The second pillar is mandatory, fully funded and privately managed; pensions are earnings-related and based on defined contributions. Contribution rates are capped at $10 \%$ plus the fee paid to the pension fund (AFP) for management and disability/survivor insurance (2.4\% on average in 2004), in addition to a compulsory $7 \%$ contribution to health insurance.

- The third pillar refers to complementary retirement plans (optional, fully funded, earnings-related, privately managed), where contributions are deductible from income taxation up to a ceiling.

There are three alternatives for the payment of retirement income: i) pensions administered by the AFPs (retiro programado), ii) annuities paid by a life-insurance company (renta vitalicia), and iii) a combination of both options, where the AFP pays a pension for a limited period and the life-insurance company pays an annuity, or the AFP pays part of the pension and the life-insurance company pays an annuity for the whole retirement period. Replacement rates are estimated to be in the neighbourhood of $50 \%$ (as of May 2004) on average for the second-pillar regime.

\section{The challenges to be addressed in the reform proposal}

The coverage of social security is low. Based on administrative records held by the pension fund industry's regulator, only about $55 \%$ of the labour force contributes to social security. This ratio is low in part because of labour informality, and also because contribution to an AFP is optional for the self-employed, who account for about $25 \%$ of total employment.

Early retirement is widespread, although there are penalties, which have been raised.

The density of contributions is low. Density is defined as the actual number of months of contribution over total potential months of contribution (i.e. 240 months, corresponding to the minimum of 20 years). Based on the regulator's administrative records, about one-half of those individuals who contribute to social security, do so for less than $60 \%$ of their potential contribution period. Many individuals, particularly females and the self-employed, have gaps in their contribution history, affecting their ability to accumulate funds to finance their retirement income.

\section{Simulations}

Simulations reported in OECD (2005) based on Berstein, Larrain and Pino (2005) suggest that, at the current level of the minimum pension, those pensioners who will not have saved enough for a retirement income above the minimum pension but will have met the requirement for a minimum pension guarantee (20 years of contribution) will account for about $10 \%$ of pensioners towards the end of the forecast period (2005-25). Also, the share of pensioners who will receive a pension below the guaranteed level and are not entitled to a guarantee is set to stabilise over time, but at a high level of about one-half of pensioners over the forecast period. These individuals would receive a pension income based on their contributions plus the returns on their investment and, in addition, can apply for an assistance pension if they have no other sources of income, once their savings have been depleted.

\section{Fiscal costs associated with the pension system}

The pension system imposes costs on the budget associated with: $l$ ) the payment of pensions to the workers who chose to remain affiliated with the old PAYG regime, ii) the redemption upon retirement, invalidity or death of recognition bonds held by those individuals who chose to migrate to the new pension system in $1980,{ }^{2}$ iii) the payment of minimum pension guarantees to retirees who have contributed to the current regime for the minimum length of time set in law, but who have been unable to save at a level that ensures a minimum pension upon retirement, and iv) the payment of assistance pensions to workers who do not meet the requirements for a minimum pension guarantee. 
The total cost of the civil pension system to the budget is approximately $2.7 \%$ of GDP in 2007 (considering the accrued interest on the recognition bonds). Current simulations show that the deficit of the old PAYG regime is set to fall from the current level of about $2.2 \%$ of GDP to about $0.4 \%$ of GDP by 2025 , while payment of minimum pension guarantees and assistance pensions will rise from about $0.5 \%$ of GDP to $1.2 \%$ of GDP in 2025 . The stock of remaining recognition bonds will have been redeemed by then.

1. See OECD (2003 and 2005), Corbo and Schmidt-Hebbel (2004) and Arenas and Mesa-Lago (2006) for more information.

2. The recognition bonds were issued to finance the transition from the old PAYG regime to the current three-pillar system. These bonds can be redeemed upon retirement (65 years for males and 60 years for females), invalidity or death. The face value of the bonds is calculated at the moment of transition to the current system to yield a pension income equivalent to $80 \%$ of average earnings during 1978-79 pro-rated for the duration of enrolment in the old system. The bonds earn a mandated rate of return of $4 \%$ per year in real terms. For more information see Arenas and Gana (2005).

The pension reform proposal currently under discussion in Congress aims at tackling the main shortcomings of the current system (low coverage and low density of contributions) and at bolstering social protection by strengthening the solidarity pillar of the pension system in an incentive-compatible manner. Once it is fully implemented, the cost of the reform is estimated at about $1 \%$ of GDP per year. Its main elements, which are by and large consistent with the policy recommendations in OECD (2005) are:

- Creation of the Solidarity Pension System (Sistema de Pensiones Solidarias) targeted at low-income individuals (males and females) of 65 years of age. The system is set to be fully operational in five years following approval of the reform package. Invalidity and old-age pensions would be means-tested but not conditional on labour-market attachment and contribution history, as in the current system. When fully operational, the system would replace the current assistance pensions (PASIS) and the minimum pension guarantee (PMG) and would benefit the low- and middle-income population (those in the bottom three income quintiles). The system would cover workers who have not contributed to social security and hence have no pension income by granting them a pension benefit (Pensión Básica Solidaria) that would be capped at CLP 75000 per month in 2009 (up from CLP 60000 per month in 2008). Those workers who have contributed to a pension fund but whose savings are not high enough to allow them to earn a retirement income higher than CLP 200000 per month in 2012 (CLP 60000 in 2008) would receive top-up payments (Aporte Previsonal Solidario). The implicit withdrawal rate associated with this top-up payment implies a $37.5 \%$ effective marginal tax on contributory pensions.

- Replacement of the AFP Superintendency by a new regulator (Superintendencia de Pensiones) and creation of an Investment Council (Consejo Técnico de Inversiones) under the new regulator to strengthen its prudential regulation capability. The institution in charge of administering the solidarity pension system (Instituto de Previsión Social, which would replace INP, Instituto de Normalización Previsional) would be under the supervisory purview of the new regulator. Agencies to improve services to pensioners and to raise awareness of pension entitlements and obligations would also be created.

- Introduction of a bonus per child to be awarded to women as means of fostering gender equality. The bonus would be equivalent to a year's contribution (on a minimum wage) to a pension fund and would earn a real rate of return equal to the average real rate earned by all C-type pension 
funds. ${ }^{3}$ Life and invalidity insurance premia would be calculated separately for males and females, resulting in lower premia for women on account of their longer life expectancy. The gender difference between these premia would be paid into the recipient's pension fund.

- Introduction of compulsory contributions to a pension fund for own-account workers, who would have access to solidarity pensions. The level of contributions would be raised over a seven-year period following approval of the reform package, and contributions for health insurance would be introduced in 10 years for these workers, as is currently the case for dependent workers.

- Introduction of a pension contribution subsidy for younger adults (18-35 years of age) during the first two years of employment for those workers earning up to 1.5 times the minimum wages. The subsidy would include a payment to the employer equivalent to one-half of a pension contribution on a minimum wage and a payment of another one-half of a pension contribution to be made directly into the worker's pension fund.

- Introduction of a subsidy for voluntary retirement saving equivalent to $15 \%$ of the amount currently saved through voluntary pension schemes. The new subsidy is targeted to mediumincome families that currently do not benefit from the existing tax incentives for saving for retirement. About 200000 contributors are expected to benefit from the new subsidy.

- Introduction of a tender among AFPs for the affiliation of workers entering the labour market as a means of fostering competition in the industry and reducing administrative costs. The tender process would select the fund manager offering the lowest fee; the contract would last for 12 months, during which period the new entrants would not be allowed to switch to another pension fund. Life and invalidity insurance (SIS) would be unbundled from fund management: insurance would be tendered for all fund-holders in the AFP system, differentiated only by gender. Finally, the ceiling on pension fund investment abroad would be raised to $80 \%$ from the current level of $45 \%$. Banks would be allowed to enter the AFP market, subject to prudential regulations to ensure the unbundling of pension fund management from banking operations. Employers would have the option of contributing to a worker's pension fund through the creation of complementary collective saving mechanisms (Ahorro Previsional Voluntario Colectivo). Of course, the scope for boosting competition among pension fund managers is constrained by the price and return elasticities of demand, which are low (Berstein and Micco, 2002). Lack of awareness by affiliates of administrative-cost differentials among fund managers also discourages competition: a survey conducted in 2002 (Encuesta de Protección Social) showed that $93 \%$ of respondents did not know the value of these costs.

Contingencies also exist with regard to the redemption of recognition bonds. Recent simulations show that, if the probability of redemption on the basis of invalidity or death is adequately taken into account, the cost to be borne by the budget associated with the unwinding of the stock of recognition bonds may be more front-loaded than previously expected (Arenas and Gana, 2005). ${ }^{4}$ This is important, because about $80 \%$ of the recognition bonds issued during 1981-2004 are yet to be redeemed, and about 30\% of redemptions during 1981-2004 were on the basis of invalidity or death. But, while the claim on the budget is likely to materialise earlier than previously projected, the fiscal cost is estimated to be somewhat lower

3. There are five types of pension funds, ranging from A to E, where A-type funds have the riskiest investment portfolios.

4. Previous simulations had been based on the expected retirement dates for the workers that chose to migrate to the new regime after 1981 and therefore hold recognition bonds. In doing so, these simulations excluded early withdrawals on the basis on death or invalidity, which are additional conditions for redeeming these bonds. 
than previously estimated due to the fact that the interest accrued on these bonds is also lower as a result of more front-loaded redemptions.

\section{Tax measures}

Chile's tax system is modern, but some inefficiencies remain (Box 3). In particular, payment of a stamp duty is due on credit and loan transactions, as well as on the issuance of fixed-income securities. The statutory rate also varies according to the maturity of the contract, currently within a range of $0.134-1.608 \%$ per month in the case of loans, although it is being reduced gradually starting in 2007 to $0.1-1.2 \%$ in 2009. As in other countries in Latin America where financial transactions taxes are in place, there are likely to be considerable efficiency losses, including through the impact that these levies may have on financial intermediation. ${ }^{5}$ The taxation of financial transactions increases the cost of loans, imposing a proportionally heavier burden on firms with limited access to the financial market, such as

\section{Box 3. Chile's tax system: An overview and main issues}

\section{An overview}

Chile's tax system has the following main characteristics:

The personal and corporate tax systems are fully integrated and account for about one-third of tax collection (Figure 4). ${ }^{1}$ There is a $17 \%$ corporate tax (Impuesto de primera categoría, IPC), an earnings tax (Impuesto de segunda categoría, ISC) and a progressive general income tax (Impuesto global complementario, IGC) with the highest marginal rate at $40 \%$. In particular:

- $\quad$ Selected investments, donations to higher-education institutions and expenditure on labour training are deductible up to a ceiling against the IPC. Non-residents pay a flat rate of $35 \%$ on profit remittances and public enterprises pay a flat rate of $40 \%$. Professional services and enterprises located in Special Economic Zones (mainly the far North and South, and Easter Island) are exempt.

- $\quad$ There is a presumptive taxation regime for unincorporated businesses in selected sectors (agriculture, small mining and transport) subject to a turnover threshold. Special tax regimes are also in place for small enterprises (annual turnover less than 3000 UTMs) based on simplified accounting, and for small taxpayers (street vendors, miners, craftsmen, etc.) based on turnover. ${ }^{2}$

- $\quad$ The ISC and the IGC are progressive and apply to the same base at the same marginal rates. Taxes are filed on an individual, rather than household, basis. The ISC is paid monthly, while the IGC is due annually. The exemption threshold is nevertheless relatively high, at 13.5 UTM per month for the IPC and 13.5 UTA per year for the IGC (121\% of monthly and annual income per capita, respectively, in 2005$)$.

The VAT is the main indirect tax, accounting for about $44 \%$ of total tax collection. Transactions are taxed at a uniform rate of $19 \%$. Exports, transport and life insurance are exempt (professional, educational and health care services are exempt). There is no registration threshold. Other indirect taxes include excises on tobacco, alcohol and fuels, import duties (at a flat rate of $6 \%$, although the effective rate is less than $2 \%$ on account of several free trade agreements) and stamp duties, which affect primarily credit operations (discussed in the main text).

Municipal taxes account for about $1.5 \%$ of GDP and comprise a property tax, municipal licenses and a vehicles registration tax. The property tax is creditable against the corporate income tax.

5. For example, empirical evidence on bank debit taxes in Latin America suggests that such instruments can have considerable disintermediation effects (Baca-Campodonico et al., 2006). 
Box 3. Chile's tax system: An overview and main issues (cont'd)

Figure 4. Composition of central government tax revenue, 1995-2005

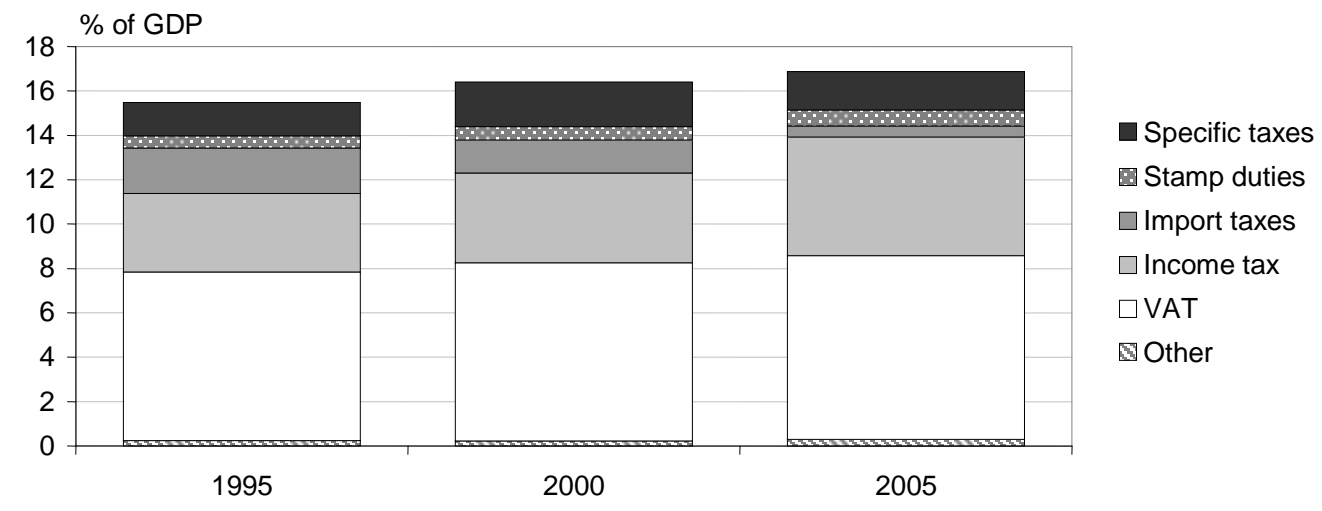

Source: SII.

1. This ratio excludes municipal tax collections and mandatory contributions to health and unemployment insurance, as well as to a pension fund (4.7\% of GDP in 2005).

2. The monthly and annual tributary units (UTM and UTA, respectively) are inflation linked measurement units expressed in CLP and used for tax purposes. The UTA is just the UTM multiplied by 12.

SMEs, for which bank lending may be the only source of financing. They have also discouraged the renegotiation of contracts, because renegotiated credits have until recently been taxed as new loans, therefore impeding competition in the banking sector. Elimination of these taxes is nevertheless constrained by the amount of revenue they yield: collection of stamp duties accounted for about $0.6 \%$ of GDP in 2006. But recent reform has aimed at mitigating these inefficiencies through a planned gradual reduction in statutory rates during 2007-09, as well as the exemption of renegotiations of loan contracts from the stamp duties.

Recent measures to modify the tax system have focused on fostering innovation and simplifying tax procedures for SMEs. To encourage investment in $R \& D$, the withholding tax due on transfers of intellectual property (consulting fees, software acquisition, etc.) was reduced to $15 \%$ of expenditure from the current level of $20-30 \%$. Also, during a 10-year period, $35 \%$ of R\&D spending will be creditable against the income tax and the remaining $65 \%$ of expenditures will be tax deductible, provided that the enterprise signs a contract with a research centre accredited by the government's development agency (CORFO) and that these contracts are registered at CORFO. Efforts to simplify tax procedures for SMEs have focused on electronic filing of taxes. The new procedure is considerably simpler: it makes use of the information available in the firm's VAT returns and accounting statements, and is both faster and cheaper for SMEs. ${ }^{6}$ Exports of services are now exempted from stamp duties and zero-rated for VAT, as is currently the case of exports of goods. Finally, the credit that currently exists for foreign investors for

6. In addition, firms may opt to have the SII provide them with a pre-filled, on-line tax return at no additional cost. The tax simplification reform also reduces the monthly provisional tax payments (therefore reducing the working capital requirement for SMEs that are not net taxpayers) and provides a strong incentive to invest, since it allows fixed assets to be depreciated instantaneously. 
investment in fixed capital in the context of bilateral tax treaties (currently at $30 \%$ of tax liabilities) has been extended to Chileans investing abroad, regardless of whether a tax treaty is in place or not. Congress has recently turned down a proposal to allow for accelerated depreciation of fixed capital investments carried out during 2007-08 as a means of encouraging private-sector investment.

There are pending issues in tax policy. The income tax encourages individuals to incorporate themselves. This is because of the discrepancy between the corporate income tax (IPC) of $17 \%$ and the top bracket of the personal income tax (ISC) of $40 \%$, and of several exemptions to the corporate income tax, including retained earnings. Several savings instruments, including social security contributions up to a ceiling, are deductible from income taxation (Serra, 1998). In addition, the tax system is in effect mildly regressive. Although the high marginal rates and exemption threshold of the personal income tax would make for high progressivity, average rates are much lower as a result of the exemptions and incentive for individuals to incorporate themselves. The personal income tax system is therefore much less progressive than in most countries in the OECD area. ${ }^{7}$ In any case, it should be noted that most of the redistributive effort in Chilean public finances that is contributing to the improvement in income distribution is carried out through the expenditure side of the budget, which may be optimum (Engel, Galetovic and Raddatz, 1999).

\section{Monetary policy}

\section{Recent trends and outlook}

Monetary policy has successfully anchored inflation expectations. The policy framework has combined inflation-targeting and a floating exchange rate regime since September 1999. Headline inflation has remained within the 2-4\% range targeted by the BCCh since 2001, except for the period from end-2003 to end-2004, when it undershot the target floor by a significant amount (Figure 5). Headline inflation remained close to the ceiling of the target range during most of 2006, and just exceeded it for very short periods, essentially on account of high energy prices, but began to converge to the mid-point of the target range towards the end of the year. More recently, due to rising energy and food prices, as well as a closing output gap, core and headline inflation have trended up and are well above the ceiling of the target range.

The policy interest rate (Tasa de Política Monetaria, TPM) was raised successively from September 2004 to end-2006 towards a more neutral stance in line with a pick-up in activity and rising unit labour costs. However, the concomitant appreciation of the peso, coupled with broadly stable inflation expectations within the target range, resulted in a sharp tightening of monetary conditions. The monetary stance was subsequently eased in January 2007 because of weak GDP readings towards end-2006 and a faster-than-expected convergence of inflation to the 3\% target. The monetary stance is likely to be tightened further towards end-2007 at a pace that will depend on changes in the international environment, the possible propagation of inflationary shocks to other prices in the economy, and the strength of economic activity. Domestic credit continues to grow at a vigorous pace, despite a deceleration since early 2007 in the consumer credit segment - a development that may be attributed to the impact of high energy prices on consumer sentiment and the concomitant monetary tightening since mid-2007.

7. Because of its uniformity, the VAT tends to be regressive, when the effect of life-time earnings on consumption decisions is not taken into account (Engel, Galetovic and Raddatz, 1999). More recent evidence that takes into account the role of retained earnings and the incentive for self-incorporation, as well as exemptions in the VAT, confirms the slight regressivity of the Chilean tax system (Cantallopts et al., 2007). 
Figure 5. Monetary stance, exchange rate and unit labour costs: Recent trends, 2001-07

\section{A. Inflation target and outturn}

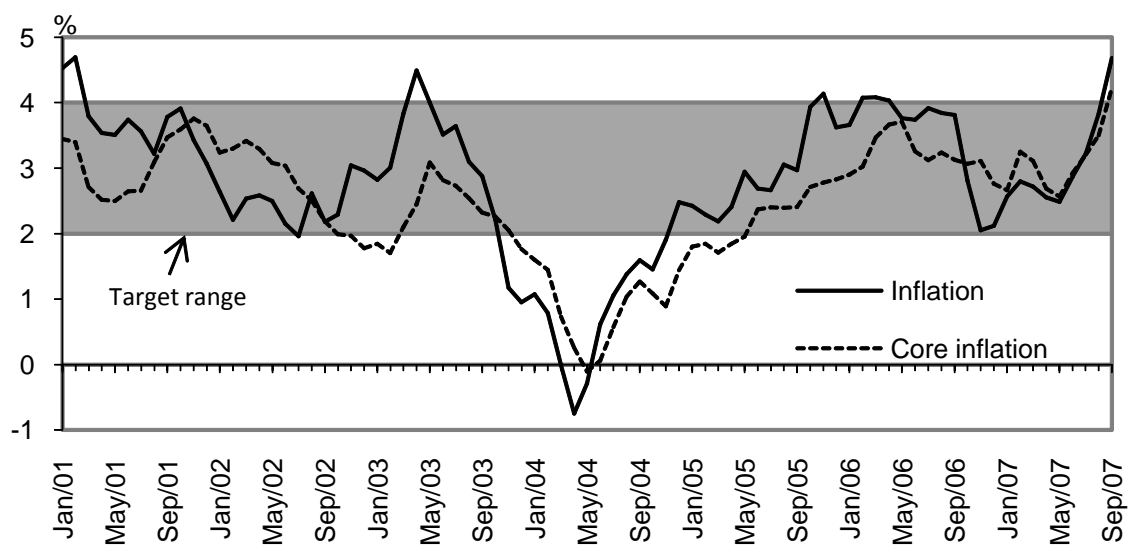

B. Monetary stance and inflation expectations

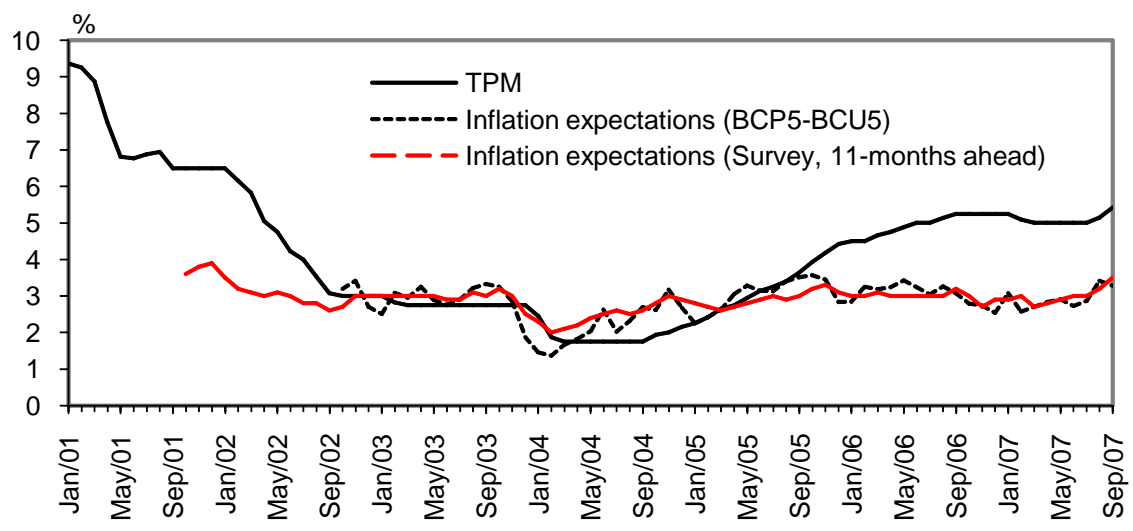

C. Exchange rate and unit labour costs (year-on-year changes)

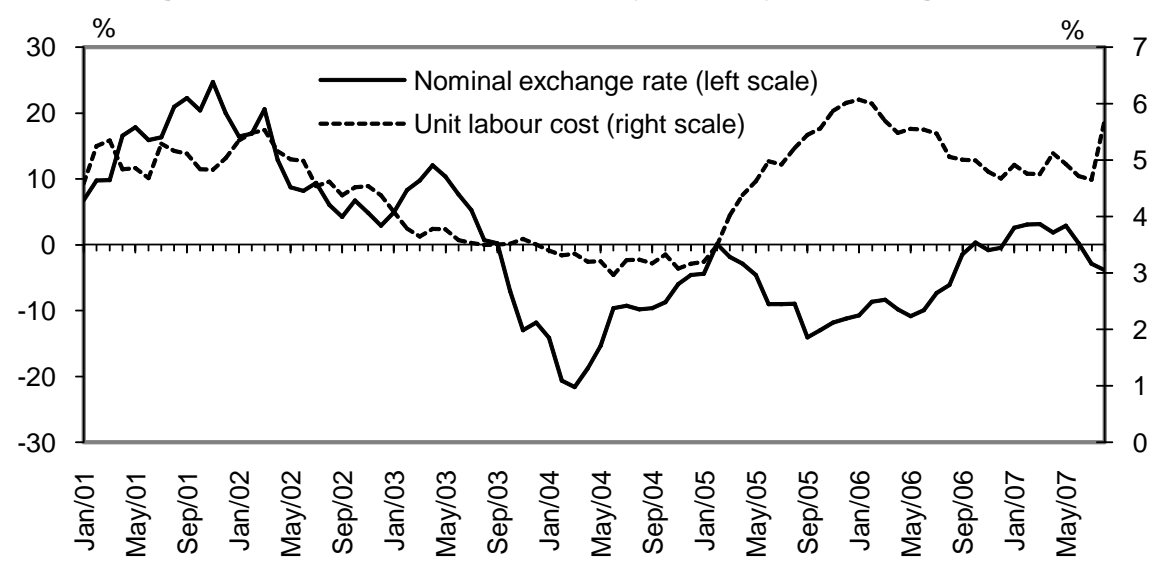

Source: Central Bank of Chile and OECD

The monetary policy framework has been instrumental in anchoring expectations around the target. The policy interest rate and the expected inflation series depicted in Figure 5 (Panel B) have tended to move together since the adoption of inflation targeting and the liberalisation of the exchange-rate regime in 
September 1999, a finding that is confirmed by the empirical evidence reported in Annex A2. In particular, the combination of exchange-rate flexibility and inflation targeting since late 1999 has allowed monetary policy to be conducted in a forward-looking manner, so that the monetary authority can react to changes in inflation expectations, rather than being encumbered by the need to defend an exchange-rate peg.

\section{Recent policy actions}

The BCCh has re-emphasised the mid-point of the inflation target and lengthened the time horizon for achieving the target. At end-2006, the BCCh issued a revision to its 2001 document on the operations of the inflation-targeting regime (Central Bank of Chile, 2006), re-defining the inflation target to 3\%, with a tolerance band of plus or minus 1 percentage point. Until then, the BCCh had stated that it would target inflation within a 2-4\% range, rather than emphasising the mid-point of the target range. At the same time, the BCCh also redefined its inflation target horizon to 2 years. Until then, it had targeted inflation within a horizon of 1-2 years.

\section{Financial deepening}

Chile's financial market is reasonably well developed. The ratios to GDP of credit to the private sector and equity-market capitalisation are high by emerging-market standards. However, turnover is low in equity markets, partly as a result of a preponderance of pension funds, which typically follow a buy-and-hold strategy on account of the long maturities of their liability portfolios. At the same time, the size of the fixed-income market (corporate and government) is comparable to that of several OECD countries in relation to GDP, and the public debt market appears to be liquid on the basis of turnover and bid-ask spread indicators. The corporate bond market is also sizeable in comparison with other emerging markets and close to the OECD average. Further financial deepening would therefore call for policy action to encourage the development of other market segments.

The Capital Market Law II (MKII) was approved in March 2007, following nearly four years of debate in Congress. The legislative process was longer than expected, which the authorities attribute to the complexity of the draft law. There is widespread recognition that the reform package could go a long way to reducing remaining impediments to further financial deepening, especially by facilitating access to risk capital for enterprises and strengthening the stock market. Banks will be allowed to invest (through their subsidiaries) up to $1 \%$ of their equity in risk-capital initiatives, and capital gains from investment in risk-capital funds will be exempted from taxation. The reform package also introduces stricter regulations for the custody of bank, insurance company and AFP certificates, which will make for greater capital-market security. A pledge registry was also created to facilitate credit operations by allowing intermediaries to know whether or not assets pledged as collateral are being used in other transactions. Also, the bankruptcy compensation framework for derivative-based transactions was brought up to international standards. At the same time, a Capital Markets Commission was created in 2006 to advise the government on areas for future reform. Moreover, recent policy initiatives have focused on facilitating Chile's financial integration in international markets. The securities and insurance regulator, SVS, aims to upgrade the offshore stock exchange to make existing information requirements more flexible for non-residents wishing to trade in Chilean markets.

Public debt management has contributed to fostering the development of the domestic fixed-income market. The Central Bank of Chile (BCCh) is the main issuer of government securities, accounting for the bulk of traded domestic debt (Ministry of Finance, 2006b) (Table 1). The Treasury issues abroad and in the domestic market, essentially through long-dated, UF-indexed securities. CODELCO, the mining company, essentially issues abroad and, therefore, provides a benchmark for other Chilean private-sector issuers, given the dearth of Treasury-issued securities in foreign markets. As recommended in OECD (2005), 
Table 1. Public debt indicators, 1995-2005

\begin{tabular}{|c|c|c|c|}
\hline \multicolumn{4}{|c|}{ In per cent of GDP } \\
\hline & 1995 & 2000 & 2005 \\
\hline \multicolumn{4}{|l|}{ Traded public debt } \\
\hline Central government $^{1}$ & 6.0 & 3.8 & 5.2 \\
\hline In CLP & 0.3 & 0.2 & 1.8 \\
\hline In USD & 5.7 & 3.6 & 3.4 \\
\hline Central bank & 28.8 & 31.2 & 16.0 \\
\hline Fixed rate & 0.0 & 4.0 & 5.6 \\
\hline UF-indexed & 27.8 & 26.2 & 7.4 \\
\hline USD-indexed/denominated & 1.1 & 2.1 & 2.6 \\
\hline Other & -0.1 & -1.1 & 0.1 \\
\hline Public enterprises $^{2}$ & 2.1 & 4.4 & 5.4 \\
\hline \multicolumn{4}{|l|}{ Memorandum items: } \\
\hline Total gross debt & 43.2 & 41.2 & 30.9 \\
\hline Consolidated $^{3}$ & 40.3 & 36.2 & 24.3 \\
\hline Public enterprises & 2.9 & 5.0 & 5.6 \\
\hline Guaranteed debt & 4.1 & 0.9 & 1.4 \\
\hline Recognition bonds & 22.5 & 19.8 & 12.0 \\
\hline Subordinated debt & 3.6 & 2.1 & 1.4 \\
\hline Consolidated net debt3 & 8.3 & 6.8 & 2.5 \\
\hline
\end{tabular}

1. Includes CORFO liabilities and excludes securities held by the central bank.

2. Excludes liabilities with the Treasury.

3. Central government and central bank.

Source: Ministry of Finance.

policy action has focused on replacing inflation- and exchange rate-indexed securities by instruments paying a nominal rate of return, which facilitates the de-indexation of the Chilean economy. The replacement of USD-denominated debt by instruments denominated in pesos has been carried out while reducing foreign reserve holdings, so as to maintain the government's net foreign asset position. Effort has been made to achieving greater coordination between the BCCh and the Treasury on debt issuance, with the Treasury focusing on the long end of the yield curve and the BCCh gearing its portfolio to short- and medium-term instruments needed for the conduct of monetary policy.

\section{Challenges and policy recommendations}

\section{The challenges}

The main challenge facing Chile in the macroeconomic area is to accommodate demands for hiking government spending, including through the reduction of the structural budget surplus target from 2008, while maintaining a lean public sector in a low-tax, low-debt environment. Although the planned increase in social spending from 2007 is consistent with continued adherence to the structural budget surplus rule and macroeconomic stability, it is important to carefully assess the impact of the resulting fiscal expansion on the effectiveness of government spending. The multiple social demands that typically arise in a country of Chile's income level and considerable income inequality will need to be satisfied while ensuring that public indebtedness remains low, which is the outcome of years of careful fiscal management, and the tax burden on businesses and individuals continues to be comparatively light, which has underpinned Chile's competitiveness and sustained its strong growth performance. 


\section{Fiscal policy}

\section{Strengthening fiscal responsibility legislation further}

The FRL makes headway in several policy areas. It includes formal mechanisms for dealing with pension-related contingencies through the creation of the Pensions Reserve Fund. This is a sensible strategy for pre-funding these contingencies within the confines of the fiscal rule, while embedding it in law. The FRL also enhances the scope for fiscal counter-cyclicality through the Unemployment and the Stabilisation funds, and deals with the long-standing need to recapitalise the central bank. These measures are consonant with the OECD's policy advice, as discussed in OECD (2003a and 2005), but there is some room for improvement in two main areas:

- The option of requiring the assets of the Pensions Reserve Fund to be invested abroad during the 10 -year period in which withdrawals cannot be made would be consistent with effort to further insulate the domestic economy from commodity price volatility.

- On the capitalisation of the central bank, benefiting from the favourable fiscal situation, it would be prudent to increase the limit set by law (0.5\% of GDP per year for five years) to allow for full recapitalisation at a swifter pace, given that the net worth of the central bank is projected at $-1.4 \%$ of GDP in 2008.

The level of the structural budget surplus to be targeted by the government was reduced in May 2007 to $0.5 \%$ of GDP from $1 \%$ of GDP. ${ }^{8}$ The 2008 budget will be drafted according to the new surplus target. The reduction of the fiscal rule's structural budget surplus target is consistent with falling net public indebtedness, diminishing central bank recapitalisation needs, sizeable fiscal savings that can be used to finance the projected cost to the budget associated with pension-related contingencies, and is understandable given the need to satisfy multiple social demands in a country of Chile's income level. The budgetary resources released through the reduction of the structural budget surplus will be used to finance additional spending on education. Although the corresponding fiscal stimulus is not expected to be destabilising, the authorities are advised to be vigilant about the cost-effectiveness of this additional spending.

\section{Making the most of pension reform}

The authorities' pension reform proposal aims to address the root causes of the contingencies that will burden the current system in the future - low coverage and low density of contributions - while strengthening social protection for the elderly. The proposed scheme improves upon the current one, because it aims at encouraging saving for retirement through capped, top-up payments for those workers who have accumulated enough assets to finance retirement income above a certain minimum level, while enhancing social protection for the poor through solidarity pensions. Instead, the current system guarantees a minimum pension only for workers who have contributed to a pension fund for a long enough period of time and does not provide any particular incentive for retirement saving. But, the strength of the incentives for saving introduced in the proposed scheme depends not only on the level of the solidarity pension, but also on the cap on, and withdrawal rate associated with, the top-up payments. While the basic thrust of the pension reform proposal is in line with the OECD's policy advice in previous Surveys, there is some scope for improvement.

It is not clear whether, at the proposed levels, the cap and the marginal tax rate on the top-up payments will create strong enough incentives for saving for retirement. Of course, this is an empirical

8. See Velasco et al. (2007) for more information. 
question. A flat uncapped, top-up scheme would provide stronger incentives for saving but would also probably be prohibitively costly. But, if needed and public finances permitting, it might be advisable to strengthen these incentives through some recalibration of the relevant parameters. In addition, the strength of the incentives for retirement saving introduced in the proposed scheme also depends on the relative value of the solidarity pension. While an increase in the value of these pensions in relation to the minimum wage undoubtedly strengthens social protection for the elderly, it also reduces the incentive for low-income workers to save through a contributory pension scheme, especially those who have never done so. Therefore, the level of the solidarity pension should be set sufficiently low in relation to the minimum wage; currently, the assistance pension is about one-half of the minimum wage, or about one-third of the median wage. This is a fair amount by OECD standards, where the average minimum retirement benefit, which includes all types of safety-nets, such as minimum and basic pensions and means-tested benefits, is just under $29 \%$ of average earnings. Because the strength of the incentives for retirement saving needs to be tested in the course of reform, gradualism is recommended during implementation, as planned by the authorities, while at the same time taking the necessary steps to raise awareness among the targeted population of the benefits of preparing for old age.

Making social security contributions compulsory for own-account workers is consistent with the policy advice made in OECD (2005). This is important because currently only 5\% of these workers contribute to a pension fund according to administrative records, while accounting for about one-quarter of employment. The problem is that these individuals may either not be able to afford coverage or perceive it as too costly in relation to the benefit of social protection, which creates incentives for non-compliance. Therefore, in addition to the recommendations above to strengthen the incentives for saving for retirement for the population as a whole, special attention should be focused on independent workers. Not only will enforcement efforts need to be stepped up considerably, but also the cost of social protection perceived by these workers will need to be gauged through regular surveys, which would allow the authorities to assess the intended population's willingness and ability to pay.

The reform proposal also makes health insurance compulsory for independent workers 10 years after approval of the reform package. But, because health insurance coverage is already high for the population as a whole, including own-account workers, it would be recommendable to make contributions for health insurance compulsory at the same time and following the same timeframe for implementation as in the case of pension contributions, rather than delaying it until 10 years after approval of the reform proposal. It is important to note that an expansion of health care services provided publicly under AUGE, discussed in Moccero (2008), would go a long way to strengthening social safety nets but would also reduce the attractiveness of health insurance for individuals on low incomes. ${ }^{9}$

Efforts to foster gender equality are welcome. Women will likely benefit from the proposed reform, because, as noted in OECD (2005), they are less likely than men to meet the length-of-contribution requirement for a minimum pension guarantee on account of their patchier labour histories, especially during their child-bearing years. Options for ensuring gender equality are welcome but should not aim at overcorrecting this imbalance by giving women a higher retirement income than those accruing to men with the same contribution history, accounting for life-expectancy differentials. Simulations suggest that the proposal for reducing the life/invalidity insurance premia paid by women relative to those paid by men on account of their longer life expectancy will overcorrect the gender imbalance that currently exists to the

9. The experience of Brazil is instructive in this regard, where a comprehensive social assistance programme for the elderly pays a pension that is equivalent to the minimum pension, regardless of contribution history and labour-market attachment, thereby reducing the incentives for social security coverage. This disincentive is exacerbated by universal access to health care. The conflict that emerges in the design of social assistance and insurance programmes is at the heart of labour informality in the country. See OECD (2006) for more information. 
detriment of women for those females with pension fund assets less than CLP 60 million. It would also be desirable to eliminate in a phased manner the gap that currently exists between the retirement age for males (65 years) and females (60 years) for the contributory pillar, given that the retirement age is proposed to be the same (65 years) for males and females in the solidarity pillar. A reduction in the age gap between males and females is a trend in the OECD area.

In the case of youths, the subsidy programme is likely to contribute to higher labour force participation, as discussed in Contreras, de Mello and Puentes (2008), and to encourage affiliation to a pension fund. However, the subsidy could be paid in full directly into the worker's pension fund, rather than one-half to be paid to the employer and the remainder into the worker's pension fund, as currently proposed.

The options envisaged for boosting competition among the pension fund managers (AFPs) are steps in the direction of reducing administrative costs. These costs have decreased over time, to $2.4 \%$ of invested funds on average (including survival and disability insurance) in 2004 but can be lowered further. The tendering of life and invalidity insurance for all fund-holders in the same AFP makes discrimination on the basis of personal medical history more difficult, which potentially improves risk pooling, and increases transparency by allowing workers to shop for the lowest premia. Also, the elimination of fixed fees for transfers of funds among AFPs will help to facilitate portability and hence to boost competition. Finally, the increase in the ceiling on assets under management that AFPs can invest abroad (from 45 to $80 \%$ ) is welcome to allow them to diversify their portfolios, and possibly seek higher rates of return, which should make portfolio management more efficient. However, as noted below, the regulatory framework for pension funds should be liberalised further in support of financial deepening.

The regulatory framework for pension fund management could be liberalized further. Chile's financial markets are dominated by the pension fund industry; therefore, reform in this area should be guided by caution and gradualism. However, the option of introducing greater flexibility in the quantitative ceilings currently in place for portfolio allocation could be considered as a means of encouraging activity in the fixed-income market. Emphasis could gradually be shifted towards prudential regulations for portfolio composition to be issued by the industry regulator, rather than mandated quantitative restrictions. Greater flexibility would likely lead to increased portfolio diversification, including through the removal of the ceiling on asset holdings abroad, and activity in the secondary-market segment for fixed-income securities. Effort to boost competition in the pension fund management market, which is worthwhile, given the extent of market concentration, would go in the direction of fostering activity in secondary fixed-income markets. Splitting asset management from administration could also be considered.

Finally, the institutional design of the pensions system may overburden the regulator. At the normative level, the current system focuses on the Superintendency for Pension Funds under the Sub-Secretary for Social Insurance. The reform proposal envisages the replacement of the current regulator by another one (Superintendency of Pensions, also under the Sub-Secretary for Social Insurance), and the creation of a Users' Commission (Comisión de Usuarios) for each AFP. ${ }^{10}$ The inclusion of the institution in charge of administering the solidarity pension system (Instituto de Previsión Social) under the supervisory purview of the new regulator may overburden it, given that the nature of regulation in the private pension system differs significantly from the administration of a first-pillar system of social protection. The new institutional set-up is more complex at the normative level; therefore, it will be important to clearly define the roles of the new institutions to avoid duplication and overlapping of

10. The Users' Commission will be composed of representatives of workers, employers, pensioners and an academic, who would chair it. The election process for each representative will be set by the Ministers of Labour and Finance. 
mandates. It is equally important to maintain the independence of the regulator in the new institutional set-up.

\section{Making the tax system more efficient}

Measures are being taken to gradually reduce the stamp duties, which are welcome, and to strengthen incentives for innovation, as recommended in OECD (2005). Gradualism is nevertheless recommended in the case of stamp duties, because revenues accruing from these levies account for about $0.7 \%$ of GDP, and because the revenue foregone and the benefits of reform in terms of efficiency gains are difficult to quantify. Also, consideration should be given to closing the gap in the income tax rates paid by individuals in the top income bracket and by corporations as a means of deterring abuse through self-incorporation. Personal expenses other than those related to the enterprise's income-generating activities cannot be included in the calculation of taxable income, which is a desirable feature of the tax code. Overall, it is important to bear in mind that, as noted above, a low tax ratio and a lean public sector are assets that should not be squandered against emerging pressures for increasing public spending on several programmes.

\section{Financing the provision of social services in a cost-effective manner}

The planned increase in social spending, while consistent with the authorities' emphasis on enhancing social protection, should be implemented in a cost-effective manner and geared towards achieving a commensurate improvement in social indicators. In some areas of social services, Chile does not differ significantly from the OECD average in the level of total spending in relation to GDP. This is the case of primary and secondary education, essentially because private spending is substantial, which compensates for comparatively low public spending levels. This discrepancy in the level of government-financed spending, which is especially large in tertiary education and health care, as discussed in Moccero (2008), would suggest that there is some scope for hiking public financing. Emphasis on housing policies is also justified, given the need to gradually close Chile's still sizeable, albeit declining, housing deficit. But it is important to bear in mind that, for an increment in public spending to deliver the expected improvements in social outcomes, it needs to be sustained over time.

\section{Monetary policy and financial deepening}

Chile's monetary framework - combining inflation targeting with exchange-rate flexibility - is working well. The maintenance of low, stable inflation for several years has allowed for further financial deepening through the development of a mortgage market, for example, a lengthening of fixed-income asset maturities and improving credit conditions. The non-bank credit market is booming, especially the business-to-customer segment, calling for enhanced efforts on the part of the BCCh to monitor developments in this area by strengthening its data collection and analysis capabilities. This is important to improve the monetary authorities' understanding of changes in the credit channel of the monetary transmission mechanism, which is likely to become increasingly potent over time.

Public debt management has an important role to play in financial-market development. An important constraint to the development of the fixed-income market is the limited supply of government debt. The Treasury does not (and will not, based on current projection) need to resort to the market for budget financing purposes, given the central government's (including the central bank) net credit position, but it is playing a role in building risk-free benchmarks for the private sector. For example, issuance of CLP-denominated long-term bonds would facilitate the pricing of same-maturity corporate bonds, for which there is robust demand by life-insurance companies. Demand for these long-dated instruments is likely to rise as pension-fund contributors retire and need to acquire life insurance annuities. Liquidity, on the other hand, is constrained by the predominance of pension fund and life insurance companies in the 
market, which tend to follow buy-and-hold investment strategies, as noted above, and the limited supply of government securities.

Against this background, it is important to formulate a debt-management strategy and clearly communicate its objectives to the market, so that debt issuance and redemptions can be carried out on a regular basis and follow a pre-announced calendar. To enhance transparency and communicability, a report on the government's Debt Management Strategy could be published on a yearly basis to complement the Ministry of Finance's Report on Public Debt Statistics (Informe de Estadísticas de la Deuda Pública), which is issued every year. In Latin America, the experiences of Brazil and Mexico in this respect are illustrative.

The authorities are rightly devising options for facilitating access to credit by small and medium-sized enterprises (SMEs). On account of their credit quality, these enterprises typically rely on bank credit for funding, rather than capital markets. In this respect, Chile is not different from most OECD countries. But there are options for mitigating natural cost and access disadvantages faced by SMEs in comparison with larger borrowers. SMEs are likely to benefit from the rapid growth of the mutual fund industry, which creates options for financing higher-yield, riskier issuers. 


\section{Bibliography}

Arenas, A. and P. Gana (2005), "Proyecciones del Gasto Fiscal Previsional en Chile, Bonos de Reconocimiento: 2005-2038”, Estudios de Finanzas Públicas, Ministry of Finance, Santiago.

Arenas, A. and C. Mesa-Lago (2006), "The Structural Pension Reform in Chile: Effects, Comparisons With Other Latin American Reforms, and Lessons", Oxford Review of Economic Policy, Vol. 22, pp. 149-67.

Baca-Campodonico, J., L. de Mello and A. Kirilenko (2006), "The Rates and Revenue of Bank Transactions Taxes", OECD Economics Department Working Paper, No. 494, OECD, Paris.

Berstein, S. and A. Micco (2002), "Turnover and Regulation: The Chilean Pension Fund Industry", Working Paper, No. 180, Central Bank of Chile, Santiago.

Berstein, S., G. Larrain and F. Pino (2005), "Cobertura, Densidad y Pensiones en Chile: Proyecciones a 30 Años Plazo", unpublished manuscript, Superintendencia de Administradoras de Fondos de Pensiones, Ministry of Labour and Social Assistance, Santiago.

Cantallopts, J., M. Jorratt and D. Scherman (2007), "Equidad Tributaria en Chile: Un Nuevo Modelo para Evaluar Alternativas de Reforma", Unpublished manuscript, Santiago.

Central Bank of Chile (2006), La Política Monetaria del Banco Central de Chile en el Marco de Metas de Inflación, Central Bank of Chile, Santiago.

Contreras, D., L. de Mello and E. Puentes (2008), "Encouraging labour force participation in Chile", OECD Economics Department Working Paper, No. 608, OECD, Paris.

Corbo, V. and K. Schmidt-Hebbel (2004), "Macroeconomic Effects of Pension Reform in Chile", unpublished manuscript, Central Bank of Chile, Santiago.

de Mello, L. and D. Moccero (2006), "Monetary Policy and Inflation Expectations in Latin America: Long-Run Effects and Volatility Spillovers", OECD Economics Department Working Paper, No. 518, OECD, Paris.

de Mello, L. and D. Moccero (2007), "Monetary Policy and Macroeconomic Stability in Latin America: The Cases of Brazil, Chile, Colombia and Mexico", OECD Economics Department Working Paper, No. 545, OECD, Paris.

Engel, E.M.R.A., A. Galetovic and C.E. Raddatz (1999), "Taxes and Income Distribution in Chile: Some Unpleasant Redistributive Arithmetic", Journal of Development Economics, Vol. 59, pp. 155-92.

Levin, A.T., F.M. Natalucci and J.M. Piger (2004), "Explicit Inflation Objectives and Macroeconomic Outcomes", Working Paper, No. 383, European Central Bank, Frankfurt.

Ministry of Finance (2006a), Informe de Finanzas Públicas, Ministry of Finance, Santiago. 
Ministry of Finance (2006b), Informe de Estadísticas de la Deuda Pública, Ministry of Finance, Santiago.

Moccero, D. (2008), "Delivering Cost-Efficient Public Services in Health Care, Education and Housing in Chile", OECD Economics Department Working Paper, No. 606, OECD, Paris.

OECD (2003a), Economic Survey of Chile, OECD, Paris.

OECD (2003b), Economic Outlook, No. 74, OECD, Paris.

OECD (2005), Economic Survey of Chile, OECD, Paris.

OECD (2006), Economic Survey of Brazil, OECD, Paris.

Serra, P. (1998), "Evaluación del Sistema Tributario Chileno y Propuesta de Reforma", Working Paper, No. 40, Central Bank of Chile, Santiago.

Velasco, A., A. Arenas, L.F. Céspedes and J.Rodríguez Cabello (2007), "Compromisos Fiscales y Meta de Superávit Estructural”, Estudios de Finanzas Públicas, Ministry of Finance, Santiago. 


\section{Annex Al}

\section{Fiscal policy over the business and copper-price cycles}

This Annex assesses empirically the behaviour of the fiscal stance over the business and copper-price cycles since 1989. Of particular importance in the analysis is the effect on the conduct of fiscal policy of a gradual decline in indebtedness - which is a key determinant of how fiscal policy is conducted over the business cycle in the OECD area - and the introduction of the structural budget surplus rule in 2001. While falling indebtedness weakens the "sustainability" motive for fiscal consolidation, the fiscal rule makes fiscal activism over the copper price cycle less likely. These hypotheses are tested below.

\section{The methodology}

The extent to which the fiscal stance has been pro- or counter-cyclical can be assessed by regressing changes in the cyclically-adjusted primary budget balance - as a measure of discretionary action - against changes in the cyclical component of the primary budget balance (i.e. the component that reacts to the business and the copper-price cycle). The intuition is that, if the estimated correlation is negative (positive), built-in stabilisers are offset (magnified) by discretionary action, which is pro-cyclical (counter-cyclical). To test the extent to which discretionary fiscal policy responds to sustainability factors, the debt-to-GDP ratio is also incorporated in the equation. In particular:

$$
\Delta B_{t}^{s}=a_{0}+\gamma \Delta B_{t}^{c}+a_{1} \Delta b_{t-1}+u_{t}
$$

where $B_{t}^{s}$ is the cyclically-adjusted primary budget balance (in relation to trend GDP) at time $t, B_{t}^{c}$ is the cyclical component of the primary budget balance (i.e. including both copper-price and business-cycle effects) (in relation to GDP), $b_{t-1}$ is the lagged public debt stock (in relation to GDP), $u_{t}$ is an error term and $\Delta$ is the difference operator. ${ }^{1}$

The interpretation of Equation (A2.1) is that if the estimated coefficient $\gamma$ is negative (positive), part of the cyclical fluctuations in the primary budget balance is offset (magnified) by discretionary action, characterising pro-cyclical (counter-cyclical) activism.

\section{Data}

Equation (A2.1) is estimated using annual data available from the Ministry of Finance on the headline budget balance, the cyclically adjusted budget balance and the cyclical component of the budget balance, which can be decomposed between the cyclical effects on public finances associated with the business cycle and with the copper price cycle. The primary budget balance was constructed by adding interest payments to the headline balance. The data set covers the period 1989-2006.

1. See OECD (2003b), Chapter 4, for more information and evidence for the Member countries. 
The results of the estimation of Equation (A1.1) by OLS are reported in Table A1.1. On the basis of these results, fiscal activism appears to have been guided essentially by debt sustainability considerations during the period of analysis: an increase in the net debt-to-GDP ratio by 1 percentage point is associated with an increase in the cyclically adjusted budget balance by about $0.5-0.6 \%{ }^{2}$

Discretionary fiscal policy appears to have been insulated from cyclical developments in both economic activity and the price of copper. Nevertheless, this was not the case before 2001. Until then, fiscal activism was counter-cyclical, as evidenced by a positive estimated coefficient on the cyclical component of the budget balance. This means that an improvement in the budget balance on account of a rising output gap or a copper price hike was accompanied by discretionary action to raise the budget balance further. This is, however, not the case after 2001, a development that may be associated with the introduction of the structural budget surplus rule. Although the results should be interpreted with caution, given the dearth of data used in the empirical analysis, they remain valid if the budget balance is corrected for the effects on public finances only of fluctuations in the price of copper.

Table A1.1. Fiscal policy over the business and copper price cycles, 1989-2006

Dep. Var.: Cyclically-adjusted primary budget balance ${ }^{1}$

\begin{tabular}{|c|c|c|c|c|c|c|c|c|}
\hline \multirow[b]{2}{*}{ Cyclical component of budget balance } & \multicolumn{2}{|l|}{1} & \multicolumn{2}{|l|}{2} & \multicolumn{2}{|l|}{3} & \multicolumn{2}{|l|}{4} \\
\hline & $\begin{array}{r}0.05 \\
(0.045)\end{array}$ & & & & $\begin{array}{r}0.01 \\
(0.085)\end{array}$ & & & \\
\hline $\begin{array}{l}\text { Cyclical component of budget balance (before } \\
\text { 2001) }\end{array}$ & & & $\begin{array}{r}0.16 \\
(0.056)\end{array}$ & ** & & & $\begin{array}{r}0.59 \\
(0.240)\end{array}$ & ** \\
\hline Cyclical component of budget balance (after 2001) & & & $\begin{array}{r}0.03 \\
(0.038)\end{array}$ & & & & $\begin{array}{r}-0.01 \\
(0.075)\end{array}$ & \\
\hline Lagged net debt-to-GDP ratio & $\begin{array}{r}0.05 \\
(0.012)\end{array}$ & *** & $\begin{array}{r}0.03 \\
(0.012)\end{array}$ & ** & $\begin{array}{r}0.06 \\
(0.021)\end{array}$ & ** & $\begin{array}{r}-0.02 \\
(0.035)\end{array}$ & \\
\hline Intercept & $\begin{array}{r}1.56 \\
(0.215)\end{array}$ & *** & $\begin{array}{r}1.54 \\
(0.223)\end{array}$ & $* * *$ & $\begin{array}{r}1.71 \\
(0.449)\end{array}$ & *** & $\begin{array}{r}1.64 \\
(0.428)\end{array}$ & *** \\
\hline Cyclical effect & Bus & ness & $\begin{array}{l}\text { ycle and } \\
\text { price }\end{array}$ & & Cor & per & rice only & \\
\hline $\mathrm{F}$ test ( $p$ value) & 0.01 & & 0.00 & & 0.04 & & 0.02 & \\
\hline R-squared & 0.65 & & 0.69 & & 0.32 & & 0.49 & \\
\hline Cyclical component is endogenous? ( $p$ value) & 0.10 & & $\ldots$ & & 0.32 & & $\ldots$ & \\
\hline
\end{tabular}

1. Heteroscedasticity-corrected standard errors are reported in parentheses. Statistical significance at the 1,5 and $10 \%$ levels is denoted by respectively $\left({ }^{* *}\right),\left({ }^{* *}\right)$ and $\left({ }^{*}\right)$. All models are estimated by OLS. The number of observations is 18 . The cyclical component of the budget balance is instrumented by its lagged value in the endogeneity test.

Source: OECD estimations.

2. The cyclical component of the budget balance may be endogenous, because fiscal activism tends to be expansionary, which affects the output gap. This is nevertheless not the case on the basis of the endogeneity test reported with the regression results. 


\section{Annex A2}

\section{Monetary policy and inflation expectations: Long-run effects}

This Annex uses co-integration analysis to empirically test whether Chile's monetary policy framework has contributed to anchoring inflation expectations around the pre-announced targets. ${ }^{1}$ Visual inspection of the interest rate and the expected inflation series in Figure 5 (Panel B) suggests that these variables have tended to move together since the adoption of inflation targeting and the liberalisation of the exchange-rate regime. These co-movements provide prima facie evidence that monetary policy has been successful in anchoring inflation expectations. But, to be sure, a more formal test is required, consisting of estimating long-run relationships among these variables using co-integration analysis.

\section{Data}

The empirical analysis was conducted using monthly data available from the central bank (BCCh). The interest rate is defined in nominal terms as the annualised TPM rate, and expected inflation is defined as the 12-month-ahead consumer price inflation (measured by the IPC) based on the market surveys conducted by the BCCh since September 2001. The sample period selected for the empirical analysis was therefore guided by the availability of information on inflation expectations. ${ }^{2}$ On the basis of conventional tests, both the interest rate and expected inflation were found to exhibit unit roots (results not reported but available in de Mello and Moccero, 2006) and were therefore first-differenced in the co-integration analysis below.

\section{Cointegration analysis}

The co-integration test was performed for the interest rate and expected inflation, because the inflation target was constant during the period after inflation expectations data started to be collected. The test was performed using the Johansen-Juselius methodology, including a constant as the only deterministic element in the vector error-correction model (VECM). The maximum number of lags included in the VECM was originally set at twelve and then selected on the basis of two different multivariate lag selection criteria: the Akaike Information Criterion (AIC) and the Schwarz Bayesian Criterion (SBC). On the basis of these tests, an optimal lag length of two was chosen on the basis of SBC and seven on the basis of AIC. The optimal structure was finally set according to SBC, since no co-integrating vector was found with seven lags.

The results of the co-integration tests are reported in Table A2.1 and indicate the presence of a unique long-term relationship between the policy interest rate and expected inflation. This suggests that the conduct of monetary policy in a regime characterised by inflation targeting and floating exchange rates has been forward-looking and effectively anchored inflation expectations.

1. This Annex is based on de Mello and Moccero (2006).

2. The option of extracting information about inflation expectations from the returns differential between same-maturity inflation-indexed and nominal bonds (BCU and BCP) is possible, but the relevant time series are too short. 
Table A2.1. Co-integration tests

\begin{tabular}{lrr|rr}
\hline & \multicolumn{2}{c|}{ MAX test } & \multicolumn{2}{c}{ Trace test } \\
\cline { 2 - 5 } $\mathrm{H}_{0}$ & $\mathrm{r}=0$ & $\mathrm{r}=1$ & $\mathrm{R}=0$ & $\mathrm{r} \leq 1$ \\
$\mathrm{H}_{1}$ & $\mathrm{r}=1$ & $\mathrm{r}=2$ & $\mathrm{R} \geq 1$ & $\mathrm{r} \geq 2$ \\
Statistics & 16.05 & 5.72 & 21.77 & 5.72 \\
Critical value (at 10\% confidence level) & 13.75 & 7.52 & 17.79 & 7.50 \\
\hline
\end{tabular}

Source: Data available from the Central Bank of Chile and OECD calculations.

The estimated co-integrating vector is: $r_{t}=-12.7+5.5 E_{t} \pi_{t+12}+e_{t}$, where $r_{t}$ is the interest rate, $E_{t} \pi_{t+12}$ is 12-month-ahead expected inflation, and $e_{t}$ is an error term. The sample spans the period 2001:9 to 2006:1. The estimated parameters suggest that the interest rate reacts to changes in expected inflation, so that monetary policy is conducted in a forward-looking manner. The magnitude of the estimated coefficient on expected inflation suggests that the conduct of monetary policy has managed to de-link private-sector inflation forecasts from realised inflation outcomes. This finding is consistent with the evidence for industrial countries reported by Levin et al. (2004) that inflation is much less persistent in countries that have explicit targets for inflation, where there is no correlation between private-sector inflation forecasts and lagged inflation. 


\section{WORKING PAPERS}

The full series of Economics Department Working Papers can be consulted at www.oecd.org/eco/Working_Papers/

604. Avoiding the value added tax: Theory and cross-country evidence (April 2008) Luiz de Mello

603. Oil Price Shocks, Rigidities and the Conduct of Monetary Policy: Some Lessons from a New Keynesian Perspective (April 2008) Romain Duval and Lukas Vogel

602. The Contribution of Economic Geography to GDP Per Capita (April 2008) Hervé Boulhol, Alain de Serres and Margit Molnar

601. Estimating a supply block for Poland

(April 2008) Rafal Kierzenkowski, Patric Ollivaud, Franck Sédillot and Philippe Briard

600. Product market regulation and economic performance across Indian states (March 2008) Paul Conway, Richard Herd and Thomas Chalaux

599. Improving product market regulation in India: an international and cross-state comparison (March 2008) Paul Conway and Richard Herd

598. Revenue buoyancy and its fiscal policy implications (February 2008) Isabelle Joumard and Christophe André

597. Monetary policy, market excesses and financial turmoil (February 2008) Rudiger Ahrend, Boris Cournède and Robert Price

596. Explaining differences in hours worked among OECD countries: an empirical analysis (February 2008) Sven Blondal and Jean-Marc Burniaux

595. Fiscal policy in India: past reforms and future challenges (February 2008) Richard Herd and Willi Leibfritz

594. The significance of Switzerland's enormous current-account surplus (March 2008) Peter Jarrett and Céline Letremy

593. Interdependencies between monetary policy and foreign-exchange intervention under inflation targeting: the case of Brazil and the Czech Republic

(January 2008) Jean-Yves Gnabo, Luiz de Mello and Diego Moccero

592. Solow or Lucas? Testing growth models using panel data from OECD countries (December 2007) Jens Arnold, Andrea Bassanini and Stefano Scarpetta

591. The private internal rates of return to tertiary education: new estimates for 21 OECD countries (December 2007) Romina Boarini and Hubert Strauss.

590. Making federalism work (December 2007) Alexandra Bibbee 
589. The wage premium on tertiary education: New estimates for 21 OECD countries (December 2007) Hubert Strauss and Christine de la Maisonneuve

588. Enhancing the benefits of financial liberalisation (March 2007) Stefan Ide, Jens Høj and Patrick Lenain

587. Improving incentives in tertiary education (March 2007) Jens Høj

586. Globalisation and the European Union: which countries are best placed to cope? (December 2007) David Rae and Marte Sollie

585. Primary and secondary education in the United States (November 2007) Peter Tulip and Gregory Wurzburg

584. Financing higher education in the United States (November 2007) Peter Tulip

583. Corporate net lending: a review of recent trends (November 2007) Christophe André, Stéphanie Guichard, Mike Kennedy and David Turner

581. Local government finances: The link between intergovernmental transfers and net worth (September 2007) Luiz de Mello

580. Boosting Austria's innovation performance improving innovation (September 2007) Willi Leibfritz and Jürgen Janger

579. Improving employment prospects in the Slovak Republic: Building on past reforms (September 2007) Andres Fuentes

578. Improving education outcomes in the Slovak Republic (September 2007) David Carey

577. Regulatory reforms in Sweden have boosted productivity (September 2007) Espen Erlandsen and Jens Lundsgaard

576. The policy determinants of investment in tertiary education (September 2007) Joaquim Oliveira Martins, Romina Boarini, Hubert Strauss, Christine de la Maisonneuve and Clarice Saadi

575. Product market competition in the OECD countries: taking stock and moving forward (September 2007) Jens Høj, Miguel Jimenez, Maria Maher, Giuseppe Nicoletti and Michael Wise

574. Too little destruction too little creation: A Schumpeterian diagnosis of barriers to sustained growth in Ukraine

(September 2007) Christian Gianella and William Tompson

573. How do the OECD Growth Projections for the G7 Economies Perform? A post-mortem (September 2007) Lukas Vogel 